\title{
INVESTIGATION OF THE INFLUENCE OF "AMARANTH" CRYOADDITIVE ON ORGANOLEPTIC AND MICROBIOLOGICAL PARAMETERS OF PROCESSED CHEESES
}

\author{
Yuriy Hachak \\ Department of Technology of milk and milk products \\ Lviv National University of Veterinary Medicine and Biotechnologies named after S. Z. Gzhytskyi \\ 50 Pekarska str., Lviv, Ukraine, 79010 \\ gachak61@mail.ru \\ Bogdan Gutyj \\ Department of Pharmacology and Toxicology \\ Lviv National University of Veterinary Medicine and Biotechnologies named after S. Z. Gzhytskyi \\ 50 Pekarska str., Lviv, Ukraine, 79010 \\ bvh@ukr.net \\ Oksana Bilyk \\ Department of Technology of milk and milk products \\ Lviv National University of Veterinary Medicine and Biotechnologies named after S. Z. Gzhytskyi \\ 50 Pekarska str., Lviv, Ukraine, 79010 \\ bilyk_oksi@ukr.net \\ Volodimyra Nagovska \\ Department of Technology of milk and milk products \\ Lviv National University of Veterinary Medicine and Biotechnologies named after S. Z. Gzhytskyi \\ 50 Pekarska str., Lviv, Ukraine, 79010 \\ gachak61@mail.ru \\ Olha Mykhaylytska \\ Department of Technology of milk and milk products \\ Lviv National University of Veterinary Medicine and Biotechnologies named after S. Z. Gzhytskyi \\ 50 Pekarska str., Lviv, Ukraine, 79010 \\ ola75@ukr.net
}

\footnotetext{
Abstract

There was grounded the expedience of using "Amaranth" cryoadditive in the technology of processed cheeses. "Amaranth" cryoadditive contains necessary vitamins and microelements of the natural origin. The use of "Amaranth" cryopowder in the processed cheeses technology allows to enrich them with vitamins, mineral substances and food fibers. The main factors of introducing "Amaranth" cryoadditive were: the normative organoleptic estimation of a product and its daily need.

Introduction of "Amaranth" cryopowder in cheese masses results in the energetic value growth along with the treating-prophylactic effect. The complicated complex of chemical and biochemical compounds, included in the composition of "Amaranth" cryopowder, allows to relate it to products with the wide spectrum of treating-prophylactic and radio-protective properties.

Organoleptic characteristics of processed cheeses with cryopowder "Amaranth" testified that experimental samples of cheese keep the tender, elastic and resilient consistence. They have the specific original taste and smell (of cream butter). They had the homogenous picture on the cut, paste of the light-yellow or yellow color with separate dots of amaranth (black-red color). The surface of experimental samples was clean, shiny, correspondent to standards.

Experimental samples had the pleasant commodity look. Processed cheese, produced using "Amaranth" cryopowder, combines in itself traditional consumption properties with technological possibilities of functional-technological ingredients of the vegetable origin.

The offered products widen the assortment of milk products of the treating-prophylactic direction.

Keywords: processed cheeses, cryopowders, amaranth, treating-prophylactic products. 


\section{Introduction}

Taking into account modern difficult ecological conditions of Ukrainian regions, there is an acute necessity in improving the food structure of the population at the expanse of increasing the quality, biological value and taste characteristics of products [1-3]. The important direction in it is their enrichment with vitamins, mineral and immune substances, especially on the natural base [4, 5]. The skilful combination of cryopowders as bioadditives and "milk" base has great perspectives in both bio-technological and social aspects [6-8]. Cryopowders are healthy for both children and adults $[8,9]$. It is most attractive to use natural vegetable bioadditives that contain the essential amount of deficit microelements and other biologically active substances in the technology of processed cheeses $[10,11]$. The urgency of using medical plants as cryopowders essentially grew in the last years $[10,12,13]$. The cryogenic technology allows to process plants effectively, having saved the most possible amount of biologically active substances in the natural ratio. At that their concentration increases in tens of times and also the level of their assimilation by the organism [10, 14-16]. The use of such additives allows to compensate the deficit of food substances, to increase the non-specific resistance of the organism to the effect of unfavorable external factors [10].

Food products play the special role in human life activity. It completely relates also to cheese, which food value is conditioned by the high concentration of milk proteins and fat, presence of irreplaceable amino acids, salts of calcium and phosphorus, necessary for the normal development of the human organism. Cheese proteins are easier assimilated than milk ones [17, 18].

The development and production of Ukrainian food products of the treating-prophylactic direction, including milk ones, are urgent. The wide spectrum of physical-chemical properties of amaranth seeds, planted in Ukraine, conditions great prospects for its use in milk products. In this connection there is offered the research as to the study of the possibility of using "Amaranth" cryoadditive as a phytoadditive in the processed cheeses technology. Along with it, there is a sufficient raw material base in Ukraine for the wide use of the amaranth raw material in milk products. The specificity of the chemical composition of amaranth seeds is determined by the following aspects: the high content of protein substances; high content of irreplaceable amino acids; more full-vale amino acid composition comparing with seed cultures; high content of lipids; high level of food fibers and presence of isomer of vitamin $\mathrm{E}$.

\section{Materials and Methods}

The experiments were realized under conditions of the scientific laboratory of the Department of Technology of milk and milk products of Lviv National University of Veterinary Medicine and Biotechnologies named after S. Z. Gzhytskyi, Ukraine. They were also realized under industrial conditions. The unified "Amaranth" cryopowder - cryoadditive was used for the studies. The recipe of processed cheese was recalculated for industrial production, namely: for $1000 \mathrm{~kg}$ of the ready product.

"Amaranth" cryopowder - the new phytoadditive (made by "The center of cryogenic technologies" LTD, Ukraine). In contains up to $16 \%$ of protein (consisted of irreplaceable amino acids for more than $30 \%$ ), near $9-11 \%$ of food fibers (cellulose). Amaranth seeds also contain the great amount of vitamins $\left(\mathrm{E}, \mathrm{A}, \mathrm{B}_{1}, \mathrm{~B}_{2}, \mathrm{~B}_{4}, \mathrm{C}, \mathrm{D}\right)$, macro- and microelements, very important for the human organism (iron, potassium, calcium, phosphorus, magnesium, cuprum and others) and also other biologically active substances [19]. Lysine, methionine and tryptophan are dominating amino acids in the almost perfectly balanced protein composition of amaranth flour.

Amaranth protein can be compared to women milk by the balance of the amino acid composition of replaceable and irreplaceable amino acids. And the content of the most important irreplaceable amino acid lysine is 30 times higher than in wheat. At the lack of lysine, food is not assimilated, and protein just "transfers" through the organism.

The special value of amaranth is in presence of such substance as squalene with the strong antioxidant effect in its composition. It is recommended at atherosclerosis and ischemic heart disease. It also decreases the cholesterol level, favors the decrease of the risk of cardio-vascular and 
cancer diseases, essentially strengthens the immune system, favors excreting slag, radio-nuclides and salts of heavy metals from the organism [20].

The experiments included the study of the optimal ratio of "Amaranth" cryopowder of components of the milk base. Doses of the offered phytoadditive were developed on the base of recommended daily norms for processed cheese consumption for different age groups, treating-prophylactic doses of bioadditives [19]. Cryopowder was introduced directly in the cheese mixture before melting. Processed cheese "Rossiysky", traditionally produced by the milk-processing industry of Ukraine, was used as a control [19].

At searching recipe components, the recipe of processed cheese "Rossiysky" was chosen as a base. The composition of the recipe included curds of cheeses "Rossiysky" and "Hollandsky" and also dry skimmed milk, peasant butter, salts-melters (sodium tripolyphosphate) and drinking water. A half of amount of dry skimmed milk itself in the process of the scientific search was replaced in the experimental sample by offered "Amaranth" cryopowder.

At the same time there were used organoleptic, technological parameters of experimental samples of processed cheese with "Amaranth" cryopowder.

The determining factor at using "Amaranth" cryadditive was to keep normative characteristics of processed cheese [19].

Components of the mixture for melting were preliminarily prepared, according to requirements of technological instructions at processed cheeses production [20]. The mixture was melt at the temperature $80-82^{\circ} \mathrm{C}$ (Fig. 1).

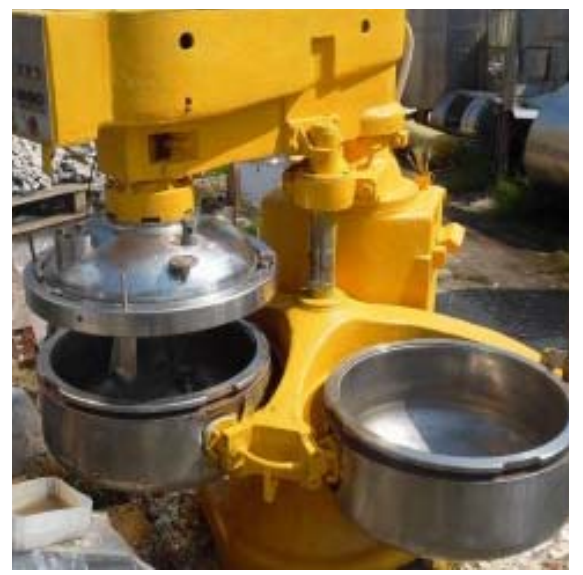

Fig. 1. Cooper of melting cheese V2-OPN $1200 \mathrm{~kg} /$ hour

The search and choice of doses of components were realized:

- at keeping maximally approximated normative characteristics of melt cheese;

- at providing taste characteristics of processed cheese with adding the offered cryoadditive. Processed cheese production consists of the following operations (Fig. 2):

The qualitative estimation of the studied cheese products was realized according to conventional methods, normative documents. SSTU ISO 707-2002 «Milk and milk products". Instructions for taking samples SSTU ISO 5538:2004 «Milk and milk products. Samples taking. Control of qualitative parameters".

Organoleptic parameters of processed cheese: look, consistence, color were determined visually, taste and smell - organoleptically.

Determination of the total amount of dry substances

Is realized as a result of subtraction of the moisture percent from " 100 ".

The mass share of dry substances in the product was calculated by the formula,

$$
\mathrm{C}=100-\mathrm{W} \text {, }
$$

where $\mathrm{W}$ - mass share of moisture, $\%$. 


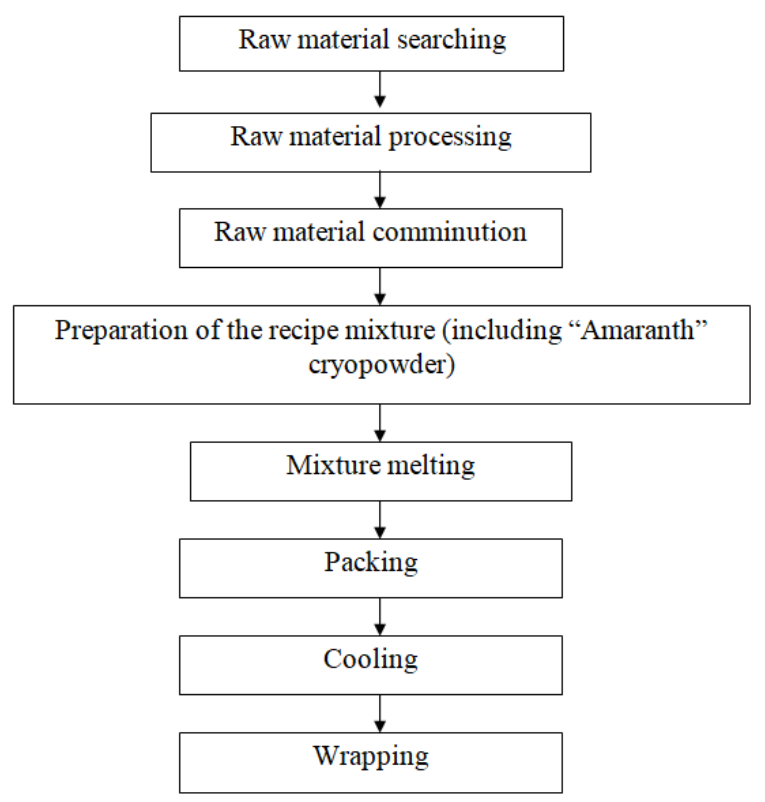

Fig. 2. Technological diagram of producing processed cheese with "amaranth" cryopowder

$3 \mathrm{~cm}^{3}$ of the studied products were put into the prepared weighing bottle by a pipette, evenly distributing it along the whole gauze surface, and weighed with the closed cover. Then the open weighting bottle and cover are paced in the drying chamber at $105^{\circ} \mathrm{C}$ for 60 minutes, after that the weighing bottle is covered, cooled and weighed. Drying and weighing are continued each 20-30 minutes for getting a difference between two successive weightings no more than $0,001 \mathrm{~g}$. Dry residue on the gauze surface must have the even light-yellow color.

\section{Determination of the amino acid composition}

The distribution and identification of amino acids were realized on an amino acid analyzer JC - 2000 (Biotronic, Germany) [8].

The composition of proteins of processed cheese with cryopowder was determined by the method of ion-exchange chromatograohy on an automatic analyzer JC-2000 (Biotronic).

\section{Results}

The organoleptic estimation of experimental samples testified that processed cheese with "Amaranth" cryopowder had the specific original taste with a tint of butter, moderately dense and a bit elastic consistence. Its surface was clean and shiny. Organleptic characteristics of processed cheese with "Amaranth" cryopowder mainly corresponded to standard requirements.

The important component at the final stage of the ready products estimation is their gustatory estimation. It is aimed at estimating taste and merchandizing characteristics. The higher mark is used at tasting for estimate the quality of products more precisely. At the point estimation processed cheeses are estimated by the scale of 30 points (table 1). At that if there are certain defects, certain discount are made and estimated in points too.

\section{Table 1}

Estimation criteria of organoleptic parameters of processed cheeses

\begin{tabular}{ccc}
\hline No. & Parameter name & Mark \\
\hline 1 & Taste and smell & 15 \\
2 & consistence & 9 \\
3 & Pastry color & 2 \\
4 & Look on cut & 2 \\
5 & Look (package, marking) & 2 \\
6 & Totally & 30
\end{tabular}


Table 2

Results of gustatory estimation of processed cheese "Rossiysky" and one with "Amaranth" cryopowder

\begin{tabular}{|c|c|c|c|c|c|c|}
\hline \multirow{3}{*}{ No. } & \multirow{3}{*}{$\begin{array}{l}\text { Parameter name of } \\
\text { processed cheese }\end{array}$} & \multirow{3}{*}{ Points number } & \multicolumn{4}{|c|}{ Tasting results } \\
\hline & & & \multicolumn{2}{|c|}{ Processed cheese "Rossiysky" } & \multicolumn{2}{|c|}{$\begin{array}{c}\text { "Cheese with "Amaranth" } \\
\text { cryopowder" }\end{array}$} \\
\hline & & & $\begin{array}{c}\text { Discount for } \\
\text { defects }\end{array}$ & Real points & $\begin{array}{l}\text { Discount for } \\
\text { defects }\end{array}$ & Real points \\
\hline 1 & Taste and smell & 15 & 1 & 14 & 1 & 14 \\
\hline 2 & Consistence & 9 & 1 & 8 & 0 & 9 \\
\hline 3 & Pastry color & 2 & 0 & 2 & 1 & 1 \\
\hline 4 & Look on cut & 2 & 0 & 2 & 0 & 2 \\
\hline 5 & Look (package, marking) & 2 & 0 & 1 & 0 & 2 \\
\hline 6 & Totally & 30 & 2 & 28 & 2 & 28 \\
\hline
\end{tabular}

As it can be seen from the results of the gustatory estimation of samples (Table 2), they all corresponded to standard requirements and received rather high characteristics (28 points of 30 possible).

At producing processed cheeses, the most important safety parameters are determined at special microbiological studies. Each of such milk products differs by certain features of microbiological studies, connected with the production technology, recipe components.

So, there was realized the microbiological assessment of the experimental samples of processed cheeses. The results of these experiments are presented in Table 3.

Table 3

Results of microbiological studies of processed cheese "Rossiysky" and one with "Amaranth" cryopowder

\begin{tabular}{|c|c|c|c|c|}
\hline \multirow{2}{*}{ No. } & \multirow{2}{*}{ Parameter name } & \multirow{2}{*}{ norm } & \multicolumn{2}{|c|}{ Processed cheese } \\
\hline & & & “Rossiysky" & With "Amaranth" cryopowder \\
\hline 1 & $\begin{array}{c}\text { Amount of mesophilic aerobic and } \\
\text { facultative-anaerobic microorgan- } \\
\text { isms (MAFAM), CFU in } 1 \mathrm{~g} \text { of } \\
\text { cheese, no more }\end{array}$ & $5 \times 10^{4}$ & $2 \times 10^{3}$ & $2 \times 10^{3}$ \\
\hline 2 & CBGB in $0,01 \mathrm{~g}$ of product & Not permitted & Not revealed & Not revealed \\
\hline 3 & $\begin{array}{l}\text { Pathogenic microorganisms, } \\
\text { including Salmonella in } 25 \mathrm{~g} \text { of } \\
\text { product }\end{array}$ & Not permitted & Not revealed & Not revealed \\
\hline 4 & Staph.Aureus in $0,01 \mathrm{~g}$ of product & Not permitted & Not revealed & Not revealed \\
\hline 5 & $\begin{array}{l}\text { Yeasts, molds, CFU, in } 1 \mathrm{~g} \text { of } \\
\text { cheese, no more }\end{array}$ & 50 & $5-6$ & $5-6$ \\
\hline
\end{tabular}

The estimation of the obtained data testifies that both traditional products and experimental samples had proper microbiological parameters that positively characterize both the technological process "culture" and products themselves. At the same time there was not revealed any harmful and dangerous microflora.

\section{Conclusions}

There was substantiated the expedience of using "Amaranth" cryoadditive in cheeses melting. This bioaditive has treating-prophylactic properties and enrich processed cheeses with numerous nutrients. At the study of organoleptic parameters of processed cheeses with "Amaranth" 
cryoadditive, there was fixed the light-yellow color of experimental samples. There were present dots of the red-black color of different sizes. The consistence was moderately dense, a bit elastic with the external luster.

The results of the gustatory estimation of processed cheese "Rossiysky" and one with "Amaranth" cryopowder testified that experimental samples received rather high characteristics. At the point estimation processed cheeses received 28 points of possible 30 that indicate complete normative consistency and high-quality commodity characteristics of processed cheeses.

At studying the microbiological estimation of processed cheese with "Amaranth" cryopowder it was established, that the amount of mesophilic aerobic and facultative-anaerobic microorganisms in experimental samples was $2 \times 10^{3} \mathrm{CFU} / \mathrm{g}$. At the same time there were not revealed microorganisms, including salmonella.

So, the use of vegetable components as bioadditives in the technological process of processed cheeses is important from both theoretical and practical points of view. The experiments in this direction are promising and interesting, they include practical recommendations for production. The result is the output of the new product, useful for potential consumers.

\section{References}

[1] Hachak, U. R., Vavrysevych, J. (2016). The use of cryopowder «Pumpkin» in the technology of cheese masses with different fat content. Scientific Messenger of LNU of Veterinary Medicine and Biotechnologies, 18 (2 (68)), 41-46. doi: 10.15421/nvlvet6808

[2] Tsisaryk, O. I., Musiy, L. Ia., Slyvka, I. M., Molokus, T. F. (2017). The development of cheese technology «Mozzarella» with the usage of different curdle ferments. Scientific Messenger of LNU of Veterinary Medicine and Biotechnologies, 19 (75), 23-28. doi: 10.15421/nvlvet7505

[3] Tsisaryk, O. I., Slyvka, I. M., Musiy, L. Ia. (2017). The research of the influence of the content of protective environment for the preservation of viability of lyophilized bacteria L. lactis and L. plantarum, from traditional Carpathian bryndza. Scientific Messenger of LNU of Veterinary Medicine and Biotechnologies, 19 (75), 29-34. doi: 10.15421/nvlvet7506

[4] Barbano, D. M., Margolies, B. (2016). Critical factors for evaluation of cheese yield performance and fat loss in large cheese factories. Journal of Animal Science, 94 (5), 269-270. doi: 10.2527/jam2016-0566

[5] Bejarano Toro, E. E., Sepulveda Valencia, J. U., Restrepo Molina, D. A. (2016). Characterization of a processed cheese spread produced from fresh cheese (quesito antioqueno). Revista Facultad Nacional de Agronomia, 69 (2). doi: 10.15446/rfna.v69n2.59146

[6] Fiol, C., Prado, D., Mora, M., Alava, J. I. (2016). Nettle cheese: Using nettle leaves (Urtica dioica) to coagulate milk in the fresh cheese making process. International Journal of Gastronomy and Food Science, 4, 19-24. doi: 10.1016/j.jigfs.2016.05.001

[7] Gutyj, B., Hachak, Y., Vavrysevych, J., Nagovska, V. (2017). The influence of cryopowder "Garbuz" on the technology of curds of different fat content. Eastern-European Journal of Enterprise Technologies, 2 (10 (86)), 20-24. doi: 10.15587/1729-4061.2017.98194

[8] Bilyk, O., Slyvka, N., Gutyj, B., Dronyk, H., Sukhorska, O. (2017). Study of the different ways of proteins extraction from sheep and cow whey for "Urda" cheese production. EUREKA: Life Sciences, 3, 3-8. doi: 10.21303/2504-5695.2017.00333

[9] Smith, G. P. S., Holroyd, S. E., Reid, D. C. W., Gordon, K. C. (2016). Raman imaging processed cheese and its components. Journal of Raman Spectroscopy, 48 (3), 374-383. doi: 10.1002/jrs.5054

[10] Shabani, J., Sarfarazi, M., Mirzaei, H., Jafari, S. M. (2016). Influence of the sunflower oil content, cooking temperature and cooking time on the physical and sensory properties of spreadable cheese analogues based on UF white-brined cheese. International Journal of Dairy Technology, 69 (4), 576-584. doi: 10.1111/1471-0307.12305

[11] Gutyj, B., Hachak, Y., Vavrysevych, J., Nagovska, V. (2017). The elaboration of cheese masses of therapeutic and prophylactic direction with cryoadditive "Pumpkin." EUREKA: Life Sciences, 1, 19-26. doi: 10.21303/2504-5695.2017.00306

[12] Bilyk, O., Slyvka, N., Gutyj, B., Dronyk, H., Sukhorska, O. (2017). Substantiation of the method of protein extraction from sheep and cow whey for producing the cheese "Urda." Eastern-European Journal of Enterprise Technologies, 3 (11 (87)), 18-22. doi: 10.15587/1729-4061.2017.103548 
[13] Turchyn, I. M., Hamkalo, Kh., Voichyshyn, A. (2017). Use of whey in the production of dessert. Scientific Messenger of LNU of Veterinary Medicine and Biotechnologies, 19 (80), 165-168

[14] Katz, G., Merin, U., Bezman, D., Lavie, S., Lemberskiy-Kuzin, L., Leitner, G. (2016). Real-time evaluation of individual cow milk for higher cheese-milk quality with increased cheese yield. Journal of Dairy Science, 99 (6), 4178-4187. doi: 10.3168/jds.2015-10599

[15] Ferrao, L. L., Silva, E. B., Silva, H. L. A., Silva, R., Mollakhalili, N., Granato, D. et. al. (2016). Strategies to develop healthier processed cheeses: Reduction of sodium and fat contents and use of prebiotics. Food Research International, 86, 93-102. doi: 10.1016/j.foodres.2016.04.034

[16] Ha, M., Sabherwal, M., Duncan, E., Stevens, S., Stockwell, P., McConnell, M. et. al. (2015). InDepth Characterization of Sheep (Ovis aries) Milk Whey Proteome and Comparison with Cow (Bos taurus). PLOS ONE, 10 (10), e0139774. doi: 10.1371/journal.pone.0139774

[17] Kaminarides, S., Nestoratos, K., Massouras, T. (2013). Effect of added milk and cream on the physicochemical, rheological and volatile compounds of Greek whey cheeses. Small Ruminant Research, 113 (2-3), 446-453. doi: 10.1016/j.smallrumres.2013.04.009

[18] Gachak, Yu. R., Gutyj, B. V., Benitska, A., Dyakun, T., Pristantsky, R., Kinitska, L. (2017). Use of «Amarant» cryoproush in the technology of dairy products of treatment and propofilactic degradation. Scientific Messenger of LNU of Veterinary Medicine and Biotechnologies, 19 (80), 57-62. doi: 10.15421/nvlvet8012

[19] Vysochina, G. V. (2013). Amaranth (Amaranthus 1.): Chemical composition and prospects of using (Review). Chemistry of plant raw material, 2, 5-14. doi: 10.14258/jcprm.1302005

\title{
OBTAINING AND CHARACTERISTIC OF THE AUTOLYSATE OF LACTIC ACID BACTERIA
}

\author{
Antonina Kapustian \\ Department of Food Chemistry \\ Odessa National Academy of Food Technologies \\ 112 Kanatna str., Odessa, Ukraine, 65039 \\ foodchem.onaft@gmail.com \\ Natalia Cherno \\ Department of Food Chemistry \\ Odessa National Academy of Food Technologies \\ 112 Kanatna str., Odessa, Ukraine, 65039 \\ cherno.onaft@gmail.com
}

\begin{abstract}
Fragments of bacterial peptidoglycan relating to compounds of the muropeptide series have high biological activity. They have an immunological effect, due to the fact that they are signals for immune receptors and, accordingly, their activators. In order to obtain fragments of peptidoglycans, the autolysis of the bacterial mass Lactobacillus delbrueckii subsp. Bulgaricus 2-11 was performed and the characteristics of protein nature products of autolysate were given. To obtain cell suspensions at different growth stages, a growth curve of the bacterial culture was constructed for 48 hours. The autolysis of biomass was carried out at the end of the logarithmic phase of growth at the temperatures $37-90{ }^{\circ} \mathrm{C}$ and after the stationary phase of growth at the temperatures $37-90$ ${ }^{0} \mathrm{C}$ for 7 days. The degree of autolytic changes was evaluated by the definition of colony forming units, the accumulation of amino acids, low molecular weight peptides and soluble protein in the autolysate. The results of studies of autolytic biomass changes have shown that the largest accumulation of amino acids occurs in autolysate, which was obtained at the end of the logarithmic phase of the growth of bacterial mass at exposures at $90{ }^{\circ} \mathrm{C}$. The molecular-mass composition of protein nature compounds of the autolysate soluble fraction is determined. It is established that peptides with a molecular weight in the range corresponding to the molecular weight of the muropeptides are presented in the autolystate, but their quantity is rather insignificant.
\end{abstract}

Keywords: lactic acid bacteria, bacteriocins, autolysis, autolysate, peptidoglycan, muropeptide. 